\title{
Publisher Correction: A fossil species of the enigmatic early polypod fern genus Cystodium (Cystodiaceae) in Cretaceous amber from Myanmar
}

\author{
Ledis Regalado ${ }^{1,2}$, Alexander R. Schmidt ${ }^{3}$, Marc S. Appelhans ${ }^{4}$, Bork Ilsemann ${ }^{5}$, Harald \\ Schneider ${ }^{6,7}$, Michael Krings ${ }^{5,8}$ \& Jochen Heinrichs ${ }^{1}$ \\ Correction to: Scientific Reports https://doi.org/10.1038/s41598-017-14985-7, published online 03 November \\ 2017
}

The original HTML version of this Article contained a typographical error in the publication date ' 03 November 2017' which was incorrectly given as '06 November 2017'. This has now been corrected in the HTML version of the Article.

(i) Open Access This article is licensed under a Creative Commons Attribution 4.0 International License, which permits use, sharing, adaptation, distribution and reproduction in any medium or format, as long as you give appropriate credit to the original author(s) and the source, provide a link to the Creative Commons license, and indicate if changes were made. The images or other third party material in this article are included in the article's Creative Commons license, unless indicated otherwise in a credit line to the material. If material is not included in the article's Creative Commons license and your intended use is not permitted by statutory regulation or exceeds the permitted use, you will need to obtain permission directly from the copyright holder. To view a copy of this license, visit http://creativecommons.org/licenses/by/4.0/.

(C) The Author(s) 2017

${ }^{1}$ Ludwig Maximilian University, Faculty of Biology, Department of Biology and Geobio-Center, Menzinger Straße. 67, 80638, Munich, Germany. ${ }^{2}$ Instituto de Ecología y Sistemática, Carretera de Varona 11835 e/ Oriente y Lindero, La Habana 19, CP 11900, Calabazar, Boyeros, La Habana, Cuba. ${ }^{3}$ University of Göttingen, Department of Geobiology, Goldschmidtstraße 3, 37077, Göttingen, Germany. ${ }^{4}$ University of Göttingen, Albrecht-von-Haller Institute for Plant Sciences, Department of Systematics, Biodiversity and Evolution of Plants, Untere Karspuele 2, 37073, Göttingen, Germany. ${ }^{5}$ SNSB-Bayerische Staatssammlung für Paläontologie und Geologie, Richard-Wagner-Straße 10, 80333, München, Germany. ${ }^{6}$ Center for Integrative Conservation, Xishuangbanna Tropical Botanical Garden, Menglun, Mengla, 666303, Yunnan, China. ${ }^{7}$ Natural History Museum, Department of Life Science, London, SW75BD, UK. ${ }^{8}$ Ludwig Maximilians University, Department of Earth and Environmental Sciences, Palaeontology and Geobiology, Richard-Wagner-Straße 10, 80333, München, Germany. Correspondence and requests for materials should be addressed to M.K. (email: m.krings@Irz.uni-muenchen.de) 